\title{
The Potential Cost of Travel Restriction on Tourism Industry
}

\author{
I Made Budiasa and Nyoman Mastiani Nadra \\ Tourism Department \\ Bali State Polytechnic \\ Denpasar-Bali, Indonesia \\ E-mail : imadebudiasa@yahoo.com; mastianinadra@yahoo.com
}

\begin{abstract}
Tourism has experienced a big increase as the result of globalization. The rise of the internet and all the online tourism businesses have recorded growth that was never possible before the globalization period. The rise of budget airlines with their online bookings, or small, cheaper accommodation providing discounted rates have attracted people to travel more. However, globalization also brings some threats to security, safety and welfare of all world communities in such interconnected world. The relatively easy interaction between world communities cannot be controlled by the government. One of the measures imposed by the government to avoid the risks of the above mentioned threats is travel restriction that ranges from travel warning to travel ban. This short paper deals with such effectiveness of the travel restriction by analyzing the possible impacts or cost on the tourism industry. Qualitative descriptive method is used in composing this paper. Data taken from some interviews with travel agents, airlines and accommodations in Bali; and references including articles, book reviews, reports, and sites in internet. The cost of nation branding is measured by the six dimensions of a country's "brand image", which include export, governance, culture and heritage, people, tourism, investment and immigration (Anholt, 2014). The findings are the travel ban imposed for any Indonesian carriers to enter the European space on the ground that many Indonesia carriers showed poor performance in terms of flight safety, following some bad accidents. The two bomb attacks, with the ensuing travel bans not only damaged the image of Bali as a welcoming island, full of tolerance to different religious beliefs or ethnic groups, but also considered as "hostile". Travel restrictions are one among a range of strategies that could be used to address a global pandemic. The grounding of airplanes in the United State after September 11, 2001 delayed the dynamics of influenza during the $2001-2002$ seasons by approximately two weeks. It is concluded that imposing travel restriction related to safety, terrorism and global pandemic must be based fairly to avoid potential damage to the tourism industry.
\end{abstract}

Keywords—potential cost; travel restriction; tourism industry

\section{INTRODUCTION}

Globalization has changed the way people travel these days. Normalization of relations between countries has led to the opening of national borders to facilitate more incoming visitors and visa has been granted relatively easier. The rise of the middle class in almost every corner of the globe, with their increased income, allow them to explore other countries to look for new experience of life and culture in many different

Thanks to Bali State Polytechnic for all the support. countries. The rise of global trade and commerce as the result of free trade agreement also caused global growth in term of world travels, whether people travel for business or leisure.

Tourism as well has experienced a big increase as the result of globalization. The rise of the internet and all the online tourism businesses have recorded growth that was never possible before the globalization period. The rise of budget airlines with their online bookings, or small, cheaper accommodation providing discounted rates have attracted people to travel more. With a click on the button, people can book an air ticket or a room without much to worry about.

The availability of information online that people can access easily offers a wide range of possibility, attracting people to travel to countries they hardly know before. Guide books are no longer consulted these days, and people can obtain updated information or websites with more accurate information compared to guide books that are printed every two or three years. Internet blogs offers a more personal review of places, yet these blogs are important sources of information for people looking for honest opinion before they make any decision to travel to a particular country, stay in a particular hotel or hang out in particular cafes.

However, globalization also brings some threats to security, safety and welfare of all world communities in such interconnected world. The relatively easy interaction between world communities cannot be controlled by the government. People can travel thousands of miles in one day, using as many different air carriers, sea liners or speedy trains links, entering many sea ports and airports in such a short time. The safety and quality flights of certain flag carriers with recent accidents give cause for concern. Terrorism has become the most fearful threat, with their ability to take many people's lives and caused millions of dollars' worth of damage. The spread of a pandemic, from bird flu to swine flu, forces the authorities to look for measure to control the possible damage.

\section{METHOD}

Qualitative descriptive method is used in composing this paper. Data taken from some resources such as interviews with travel agents, airlines and accommodations in Bali; and references including articles, book reviews, reports, and sites in internet.

Theoretically, the cost of nation branding is measured by the six dimensions of a country's "brand image", which include the following: export (public's image of products and 
services from a country), governance (public opinion regarding the level of government competency), culture and heritage (perceptions on each nation's heritage), people (the population's reputation for competence, education, openness and friendliness, as well as perceived levels or potential hostility and discrimination), tourism (the level of interest in visiting a country and the draw of natural and man-made tourist attraction), investment and immigration (the power to attract people to live, work or study). (Anholt, 2014)

\section{FINDINGS AND DISCUSSION}

One of the measures imposed by the government to avoid the risks of the above mentioned threats is travel restriction that ranges from travel warning to travel ban. Does this travel restriction achieve what it sets to achieve? What is the potential cost of the travel restriction for the tourism industry in the receiving or host countries? This paper deals with such effectiveness of the travel restriction by analyzing the possible impacts or cost on the tourism industry.

Travel restrictions, in the forms of travel warning or travel ban is imposed by a particular country to safeguard their citizens. For the past years we have observed that travel warning has been issued by country or countries with considerable power in terms of economy or better political standing. Since July 2007 the travel ban imposed for any Indonesian carriers to enter the European space on the ground that many Indonesia carriers showed poor performance in terms of flight safety ${ }^{1}$ and the US has downgraded the country to ICAO Category 2 which means that Indonesian carriers cannot add or begin new service to the US, which also has warned its citizens not to fly on Indonesian airlines ${ }^{2}$. This result from some accidents that include the fatal flight of Adam Air Flight 574 on January 1, 2007 at Makassar Strait killed 102 people and Garuda Flight 373-400 on March 7, 2007 at Adi Sucipto Airport in Yogyakarta that killed 21 of 140 passengers. This shows how this measure is used for possible commercial gains or winning competition with such unfair practices. If we look at the record of accidents in European airports, the accident in a Spanish airport should be taken as an example that European carriers also need a thorough review on their own flight safety and regulations. Although Garuda has started its flight to Amsterdam and continue to London in 2014, but travel restriction need to be considered $^{3}$.

Such asymmetrical measure, when we consider European Union as a group of 27 countries, a powerful one indeed, is actually imposed with the damage being suffered by the Indonesian carriers and the passengers flying between these

\footnotetext{
${ }^{1}$ Thomas, G. (2008, January). Indonesia's safety crisis. Air Transport World, 45(1), S10. Retrieved from

http://go.galegroup.com/ps/i.do?id=GALE $\% 7 C A 175170951 \& v=2.1 \& u=p t n 01$

0\&it=r\&p= GPS\&sw=w\&asid=f9e01d99572ce8f8c3fe6ed2bb0a5491

${ }^{2}$ Thomas, G. (2009, May). The last weak link. Air Transport World, 46(5),

21. Retrieved from

http://go.galegroup.com/ps/i.do?id=GALE $\% 7 C A 200065402 \& v=2.1 \& u=p t n 01$ $0 \& \mathrm{it}=\mathrm{r} \& \mathrm{p}=\mathrm{GPS} \& \mathrm{sw}=\mathrm{w} \& \mathrm{asid}=\mathrm{a} 61611 \mathrm{e} 06 \mathrm{c} 31467806 \mathrm{~d} 8269 \mathrm{~b} 3 \mathrm{f} 864850$

${ }^{3}$ Garuda Indonesia To Launch The First-Ever Non-Stop Flight Between Jakarta And Amsterdam. (2014, Mar 18). M2 Press wire Retrieved from http://search.proquest.com/docview/1508132624?accountid=38628
}

two regions. It does not achieve what is supposed to, which is to safeguard the lives of passenger or avoid possible damage, but rather forcing the European flight standards regulation to Indonesian carriers without allowing the Indonesian authority to have their say on the matter. The potential damage caused by this travel restriction is indeed significant to the travel business and tourism industry. Imagine the number of passengers from such European countries who will have to switch their itinerary and choose other carriers instead to come to Indonesia or fly with the Indonesian carriers. The potential loss arising from such flight ban can also be measured by the amount of loss due to the accommodation cancellation. Thus, such travel restriction cause potential damage to almost all of country's "brand image" dimensions, especially on tourism dimension.

The threat of terrorism has also forced some countries to impose travel ban to particular countries, accused of harboring terrorist groups or simply for having some religious extremists living within the country's border. Although it is justifiable that every country wants to protect their citizens from harm, travel ban for this particular case only serve to unfairly portray such particular country as the host of terrorists.

For the tourism industry, such measure runs against the nation branding campaign. In the case of Indonesia or Bali to be more specific, the two bomb attacks, with the ensuing travel bans not only damaged the image of Bali as a welcoming island, full of tolerance to different religious beliefs or ethnic groups, but somewhat reinforcing the image that the island has now been infiltrated by terrorist cells of the allegedly Jamaah Islamiyah clan ${ }^{4}$.

The cost of nation branding is enormous, as it is measured by the six dimensions of a country's "brand image", which include the following: export (determining the public's image of products and services from a country), governance (public opinion regarding the level of government competency), culture and heritage (global perceptions on each nation's heritage), people (the population's reputation for competence, education, openness and friendliness, as well as perceived levels or potential hostility and discrimination), tourism (the level of interest in visiting a country and the draw of natural and man-made tourist attraction), investment and immigration (the power to attract people to live, work or study) ${ }^{5}$.

The travel ban therefore only serves to damage almost all the above mentioned dimensions, especially the people element, where judging from the number of white Caucasian/ Christian casualties from the first Bali bomb attacks, Indonesia/ Bali are considered or portrayed as the land or country "hostile" to such visitors. Such unfavorable image damages the tourism industry that to some extent relies on the perception of such tolerable Indonesian/ Balinese community. Although it is well understood that the perpetrators are not the native people of the islands and some of the terrorist leaders

${ }^{4}$ Suter, K. (2003, 01). Terror in paradise: The Bali bombing. Contemporary Review, 282, 1-6. Retrieved from

http://search.proquest.com/docview/204761939?accountid=38628

${ }^{5}$ The Anholt - GfK Roper Nation Brands Indexsm : 2014 Report for Scotland. Retrieved from http://www.gov.scot/Resource/0046/00466977.pdf 
are not from Indonesia, damage has been done and tourism industry will have to suffer.

The global interconnection where people traveling borders at ease has become a major concern at the outbreak of new streams of virus. The bird flu and the more recent one, the swine flu that is believed to have originated in Mexico, led some countries to impose a travel restriction as a desperate attempts to stop the spread of the virus. This too have some impact on the tourism industry.

While travel restrictions alone do little to ameliorate the pandemic, they can buy time to develop and deliver vaccine and institute a range of powerful non-pharmaceuticals interventions (e.g. social distancing, public education, staging of medical equipment), all of which sharply reduce cases. Consequently, travel restrictions are one among a range of strategies that could be used to address a global pandemic. The grounding of airplanes in the United State after September 11, 2001 delayed the dynamics of influenza during the 2001 2002 seasons by approximately two weeks. The global spread such as transfer of pandemic flu from Asia or Europe to United States (or other country), could be delayed more significantly by international travel restrictions ${ }^{6}$. The Hong Kong government on Jun 9, 2015 issued a red travel warning for South Korea in view of the rising health risk from the ongoing outbreak there of the Middle East Respiratory Syndrome (MERS) ${ }^{7}$. Zika virus is causing serious concerns in Brazil as well as the Caribbean, Central America, Mexico, Puerto Rico, and South America. ${ }^{8}$

\section{CONCLUSION AND SUGGESTION}

Imposing travel restriction on matters related to safety, terrorism and global pandemic must be based fairly to avoid potential damage to the tourism industry. Travel restriction imposed to improve the flight standard and regulation should be based on objectivity, with facts and figures established through reliable fact finding mission as the hastily imposed travel restriction will only damage the tourism industry. Using travel restriction as an asymmetrical tool, used by the bigger and more powerful countries, to win competition should be avoided. In matters related to terrorism, cooperation in national security arrangement and intelligence would assist a great deal in stemming further terrorist attacks, while travel restriction will only harm the receiving country in terms of nation branding. As for the threat of global pandemic, the tourism industry should be protected. Imposing travel restriction is acceptable as an alternative for disease control, as

${ }^{6}$ Epstein JM, Goedecke DM, Yu F, Morris RJ, Wagener DK, Bobashev GV (2007) Controlling Pandemic Flu: The Value of International Air Travel Restrictions. PLoS ONE 2(5): e401. doi:10.1371/journal.pone.0000401. Retrieved from

http://journals.plos.org/plosone/article?id=10.1371/journal.pone.0000401 ${ }^{7}$ H.K. issues red travel warning for S. korea over MERS update1]. (2015, Jun 09). Kyodo News Service. Retrieved from

http://search.proquest.com/docview/1688548109?accountid=38628

${ }^{8}$ Zika virus: Latest updates, travel warnings and insect shield prevention tactics. (2016, Feb 08). M2 Presswire Retrieved from

http://search.proquest.com/docview/1762935381?accountid=38628 long as it is conducted in a well-planned manner to avoid disruption of tourism activity.

\section{References}

[1] Bird flu leads to new import restrictions on US poultry products. (2015, Mar 13). Progressive Digital Media Food News Retrieved from http://search.proquest.com/docview/1670147804? accountid=38628.

[2] Douglas, K. (2008). Translating trauma: witnessing Bom Bali. ARIEL, 39(1-2), $\quad 147+. \quad$ Retrieved from http://go.galegroup.com/ps/i.do?id=GALE\%7CA190340829\&v=2.1\&u= $\mathrm{ptn} 010 \& \mathrm{it}=\mathrm{r} \& \mathrm{p}=\mathrm{GPS} \& \mathrm{sw}=\mathrm{w} \& \mathrm{asid}=1 \mathrm{bfb} 70 \mathrm{f} 99 \mathrm{ede} 1 \mathrm{f} 4 \mathrm{ee} 0 \mathrm{f} 2 \mathrm{c} 500 \mathrm{e} 8 \mathrm{~b} 1 \mathrm{f} 18$ 9.

[3] Epstein JM, Goedecke DM, Yu F, Morris RJ, Wagener DK, Bobashev GV (2007) Controlling Pandemic Flu: The Value of International Air $\begin{array}{llcr}\text { Travel Restrictions. PLoS } & \text { ONE 2(5): } & \text { e401. } \\ \text { doi:10.1371/journal.pone.0000401. } & \text { Retrieved } & \text { from }\end{array}$ http://journals.plos.org/plosone/article?id=10.1371/journal.pone. 000040 1.

[4] H.K. issues red travel warning for S. korea over MERS update1]. (2015, Jun 09). Kyodo News Service. Retrieved from http://search.proquest.com/docview/1688548109?accountid=38628.

[5] Indonesian Carrier Garuda Hopes to Fly Europe Route Again In 2010. (2009, January 1). AsiaPulse News. Retrieved from http://go.galegroup.com/ps/i.do?id=GALE\%7CA191369292\&v=2.1\&u= ptn010\&it $=r \& p=$ GPS\&sw $=$ w\&asid $=48$ aale $360 \mathrm{~b} 42 \mathrm{a} 990 \mathrm{fa} 9 \mathrm{ac} 55 \mathrm{f} 23 \mathrm{e} 81 \mathrm{e}$ $4 \mathrm{f}$

[6] Mathews, N. (2002). Bali blast: Carriers find no place is safe. Aviation Week \& Space Technology, 157(17), 52. Retrieved from http://search.proquest.com/docview/206098471 ?accountid=38628.

[7] Mexico begins swine flu shutdown. (2009, May 01). Journal of CommerceRetrieved

http://search.proquest.com/docview/312972923? accountid=38628.

[8] Mexico to shut down business to fight swine flu. (2009, Apr 30). Journal of Commerce Retrieved from http://search.proquest.com/docview/312972868?accountid=38628.

[9] Qantas sees cancellations after bali bombs. (2005). Airline Industry Information, $1 . \quad$ Retrieved from http://search.proquest.com/docview/210548325? accountid=38628.

[10] Reinberg, S. (2012, 02). H1N1 'swine' flu makes a comeback in mexico.U.S.News \& World Report, 1. Retrieved from $\mathrm{http}: / /$ search.proquest.com/docview/927904778? accountid=38628.

[11] SkyScanner: Mexico's tourist industry recovering from swine flu outbreak reports skyscanner. (2009, Jun 04). M2 Presswire Retrieved from http://search.proquest.com/docview/446138294?accountid=38628.

[12] Sukma, R., Ma'ruf, J., \& Abdullah, K. (2011). The attitude of Indonesian Muslims towards terrorism: an important factor in counter-terrorism? Journal of Human Security, 7(1), 21+. Retrieved from http://go.galegroup.com/ps/i.do?id=GALE\% 7 CA257993854\&v=2.1\&u= $\mathrm{ptn} 010 \& \mathrm{it}=\mathrm{r} \& \mathrm{p}=\mathrm{GPS} \& \mathrm{sw}=\mathrm{w} \& \mathrm{asid}=\mathrm{d} 928213 \mathrm{a} 70 \mathrm{c} 2 \mathrm{f} 0943162 \mathrm{ddc} 65 \mathrm{bc} 78$ $45 \mathrm{e}$.

[13] The Anholt - GfK Roper Nation Brands Indexsm : 2014 Report for Scotland. Retrieved from http://www.gov.scot/Resource/0046/00466977.pdf.

[14] The European Union has lifted an ban on Garuda Indonesia, Airfast Indonesia, Mandala Airlines and Premiair from operating within the EU. (2009, August). Air Cargo World, 12. Retrieved from http://go.galegroup.com/ps/i.do?id=GALE $\% 7 C A 228947660 \& v=2.1 \& u=$ $\mathrm{ptn} 010 \& \mathrm{it}=\mathrm{r} \& \mathrm{p}=\mathrm{GPS} \& \mathrm{sw}=\mathrm{w} \& \mathrm{asid}=543296 \mathrm{~d} 2 \mathrm{~b} 79 \mathrm{cf} 468 \mathrm{~d} 5 \mathrm{fd} 196 \mathrm{cbdf} 3 \mathrm{fb}$ $5 \mathrm{f}$.

[15] Thomas, G. (2008, January). Indonesia's safety crisis. Air Transport World, 45(1), S10. Retrieved from http://go.galegroup.com/ps/i.do?id=GALE\%7CA175170951\&v=2.1\&u= $\mathrm{ptn010 \& it}=\mathrm{r} \& \mathrm{p}=\mathrm{GPS} \& \mathrm{sw}=\mathrm{w} \& \mathrm{asid}=\mathrm{f9e} 01 \mathrm{~d} 99572 \mathrm{ce} 8 \mathrm{f} 8 \mathrm{c} 3 \mathrm{fe} 6 \mathrm{ed} 2 \mathrm{bb0a54}$ 91.

[16] Thomas, G. (2009, May). The last weak link. Air Transport World, 46(5), 21. Retrieved from http://go.galegroup.com/ps/i.do?id=GALE\%7CA200065402\&v=2.1\&u= 
$\mathrm{ptn} 010 \& \mathrm{it}=\mathrm{r} \& \mathrm{p}=\mathrm{GPS} \& \mathrm{sw}=\mathrm{w} \& \mathrm{asid}=\mathrm{a} 61611 \mathrm{e} 06 \mathrm{c} 31467806 \mathrm{~d} 8269 \mathrm{~b} 3 \mathrm{f} 864$ 850.

[17] UN: Security council condemns bomb attacks in bali, indonesia; regards acts as threat to international peace; resolution 1438 (2002) adopted unanimously. (2002, Oct 15). M2 Presswire Retrieved from http://search.proquest.com/docview/443876264? accountid=38628.

[18] US to invest additional $\$ 330 \mathrm{~m}$ to contain bird flu outbreak. (2015, May 07).Progressive Digital Media Food News Retrieved from http://search.proquest.com/docview/1679396737?accountid=38628.
[19] With western travel warnings lifted, zimbabwe moves to revive tourism. (2009). (). Lanham: Federal Information \& News Dispatch, Inc. Retrieved http://search.proquest.com/docview/190545893? accountid=38628.

[20] Zika virus: Latest updates, travel warnings and insect shield prevention tactics. (2016, Feb 08). M2 Presswire Retrieved from http://search.proquest.com/docview/1762935381?accountid=38628 